\title{
Open Market Repurchases and Signaling Hypothesis
}

\author{
Vandana Gupta \\ Finance, FORE School of Management, New Delhi, India \\ Email: vandana@fsm.ac.in
}

How to cite this paper: Gupta, V. (2018) Open Market Repurchases and Signaling Hypothesis. Theoretical Economics Letters, 8, 592-608.

https://doi.org/10.4236/tel.2018.83041

Received: January 18, 2018

Accepted: February 20, 2018

Published: February 23, 2018

Copyright $\odot 2018$ by author and Scientific Research Publishing Inc. This work is licensed under the Creative Commons Attribution International License (CC BY 4.0).

http://creativecommons.org/licenses/by/4.0/

\section{c) (7) Open Access}

\begin{abstract}
This paper analyzes the impact of open market repurchase (OMR) route of buyback on the stock prices of a data set of 30 Indian listed firms which had gone for buyback in the FY16. The author has applied event study methodology to calculate abnormal returns and cumulative abnormal returns on stocks using BSE 500 as market index. The returns are calculated for 20 days prior and post buyback announcement to test for information signaling hypothesis. The analysis shows that average abnormal return (AAR) on the date of announcement is -0.23 percent while cumulative abnormal return (CAR) is about 5.72 percent on the announcement date with an overall CAR 3.44 percent for 40-day event window. The research findings reveal that unlike tender offers, OMR does not lead to a signaling effect as there is the insignificant impact on stock prices. Market reaction to buyback offer is in contradiction to signaling hypothesis predictions. The results of the study imply that the information related to the announcement of the buyback is already reflected in the share price. This also throws light on the growing maturity and efficiency of the stock market of India. Analyzing the signaling effect through OMR reveals that rather than signaling hypothesis, market reaction to buybacks is better explained by free cash flow hypothesis.
\end{abstract}

\section{Keywords}

Buyback, Signaling, Event Study, Abnormal

\section{Introduction}

A buyback, also known as a repurchase, is the purchase by a company of its outstanding shares that reduce the number of its shares on the open market. A company may decide to buy back its shares for one of the following reasons:

- To return surplus cash to shareholders as an alternative to a higher dividend 
payment or investing the surplus cash in existing or new operations (cash flow hypothesis).

- To adjust or change the company's capital structure quickly, say for those companies seeking to increase its debt/equity ratio (leverage hypothesis).

- To increase earnings per share and net asset value per share as a possible signal to the market place that management is of the view which the prospects of the company justify a market price higher than that currently accorded by the market (signaling hypothesis).

- To improve the various performance parameters like EPS, DPS, operating cash flow per share, etc.

Some of the positive aspects of buyback include:

- The market generally interprets share buy-backs as a positive signal.

- Shareholders have a choice of deciding whether or not to receive the payout by selling or holding their shares, unlike a dividend payout.

- Returning excess cash by way of a share buy-back gives a company greater flexibility with regard to its dividend policy.

- Share buy-backs could enable a company to achieve its desired capital structure more quickly or facilitate a major restructuring.

- A share buy-back could avert a hostile takeover bid by reducing the number of shares in circulation.

\subsection{Among the Negative Aspects of Buyback or Fallout of Buyback Are}

- The repurchase of its own shares by a company may conversely have a negative signaling effect as the market place may think that the company has fewer growth opportunities after a share buy-back, due to erosion of cash resources.

- Management may not seek to utilize any existing excess cash effectively by acquiring new investments or developing profitable markets.

- Possible mismanagement may arise if too high a price is paid for the re-purchased shares, to the detriment of remaining shareholders, or if cash resources are eroded to the level that could give rise to a risk of insolvency at the expense of its creditors.

- If buy-back is undertaken by replacing shares with debt in cases where companies do not have adequate funds for buy-back of shares, the proposal may prove detrimental on the company.

- A return of funds by way of a share buy-back is less certain than an annual dividend stream.

\subsection{Types of Buyback}

A company can announce its buyback using either Open Market Repurchase (OMR) method or the Fixed Price Tender (FPT) offers. Besides these two methods, SEBI's regulations permit the companies to buyback their shares through 
other methods like reverse rights issue, reverse book building (also known as Dutch Auctions in the US), purchase of employee stock options and odd-lot shares. The provisions do not permit negotiated deals or targeted repurchases. An OMR differs from an FPT. An OMR is an open offer to all the shareholders at the existing market price while an FPT is an offer at a specified price for a specific quantity. The offer price is generally at premium to market price. It is said an OMR is a flexible and non-serious method of acquiring shares and is used to return free cash flows as a substitute to dividends. The FPT is time bound and is used to correct market under valuation and to thwart the threat of hostile takeovers.

To summarize, buybacks can be carried out in three ways:

\section{Fixed Price Tender}

Shareholders may be presented with a tender offer where they have the option to submit, or tender, a portion of or all of their shares within a certain timeframe and at a premium to the current market price. This premium compensates investors for tendering their shares rather than holding on to them.

\section{Open Market}

Companies buy back shares on the open market over an extended period of time and may even have an outlined share repurchase program that buys back shares at certain times or at regular intervals.

\section{Dutch auction}

The introduction of the Dutch auction share repurchase in 1981 allows an alternative form of tender offer. A Dutch auction offer specifies a price range within which the shares will ultimately be purchased. Shareholders are invited to tender their stock, if they desire, at any price within the stated range. The firm then compiles these responses, creating a demand curve for the stock. The purchase price is the lowest price that allows the firm to buy the number of shares sought in the offer, and the firm pays that price to all investors who tendered at or below that price. If the number of shares tendered exceeds the number sought, then the company purchases less than all shares tendered at or below the purchase price on a pro rata basis to all who tendered at or below the purchase price. (In India, SEBI hasn't considered this type of Buyback).

Several companies in US followed the buyback route during the 1980s, though the concept was prevalent from much earlier. UK also introduced this concept in 1980s though for other European countries, buyback route was followed during the 1990s.

In India till 1998 share buybacks were prohibited but the Companies (Amendment) Act 1999 introduced Section 77A, 77AA and 77B in the Companies Act, 1956 permitting companies to buy-back their own shares and other securities. Further, the Securities and Exchange Board of India (SEBI) framed the SEBI(Buy Back of Securities) Regulations, 1999 and the Department of Company Affairs framed the Private Limited Company and Unlisted Public company (Buy Back of Securities) rules, 1999 pursuant to Section $77 \mathrm{~A}(2)(\mathrm{f})$ and (g) respectively. 
Typically companies which may find a share buy-back scheme feasible would be those with a high net surplus cash position, a low debt/equity ratio, high need for capital expenditure requirements in future and those with a high dividend yield. Commonly, companies, which are of view, that the intrinsic value of the shares of the company is substantially higher than the market price of the shares of the company may consider for a share buyback.

It is against this backdrop that this research paper identified 30 companies which had gone for open market repurchases during 2016 and tested for signaling hypothesis using event study methodology.

\section{Literature Review}

There is an extensive empirical research available on various aspects of share buybacks which include motives for buyback, signaling impact, post-buyback operating performance, liquidity, effect on promoters' stockholding etc. The signaling hypothesis and free cash flow hypothesis have been viewed as a basic explanation for the share repurchases. According to the signaling hypothesis, managers employ repurchases to reduce information asymmetry and signal their desire for improved market valuations. The announcement of premium buybacks conveys to the market the managers' confidence that the share is worth more than current market value. Prior works have been focused on the signaling, and cash flow hypothesis as also multiple buybacks by companies.

Research on the free cash flow hypothesis was done by Isagawa 2000 [1] concludes in his paper that where the manager has an ownership in the firm, the announcement of a repurchase plan may be a credible signal, which the manager does not want to waste the free cash flow on unprofitable projects. Buyback reduces the amount of free cash flow available in the hands of managers and resolves the agency conflict over the use of excess cash flow, Jensen M.C 1986 [2], Stephens and Weisbach 1998 [3].

Among some of the earlier works, Vermaelen 1981 [4] tested the signaling hypothesis on US firms and found that markets reach positively to buybacks through tender offers, and firms also witness increase in earnings per share post buyback. Ikenberry et al. 1995 [5] analyzed the impact of open market repurchases on stock returns, both in the short-run and the long run. Their findings were that firms witnessed negative abnormal returns in the period from 20 days to 3 days prior to buyback, and positive abnormal returns from two days before to two days after the buyback. For the long term, positive abnormal returns were observed up to 3 years post buyback. Comment and Jarrell 1991 [6] compared the relative signaling power of three buyback methods. Their research showed that the strongest signal in share price is obtained through a fixed price tender offer, followed by Dutch auction tender offer and then through open market offer.

Research studies in the past cast doubts over signaling power of repurchases carried through OMRs. Comment and Jarrell (1991) found that the cumulative 
abnormal returns were only $2.3 \%$ for OMRs as against $11 \%$ for FPTs. Kim 2008 [7] examined changes in daily return volatility associated with open market share repurchases and analyzed that an open market share repurchase firm, by actively buying back its shares when the share price falls, reduces daily return volatility. The results suggested that it is the subsequent actual buyback trading activity, not the announcement that is significantly negatively associated with changes in daily return volatility. Stanley 2003 [8] analyzed the buyback programs of Fortune 1000 companies. Primary research was conducted by administering questionnaire to companies' executives to determine the motivations for going in for a stock buyback program. Among the reasons, the first reason cited was that repurchase is paid, and not cash dividends to signal that excess cash flow was temporary in mature, the second reason cited was to offset dilution because of stock options, and the signaling effect was the third in order of priority. Therefore, this study contradicted the signaling hypothesis of buyback as the sole reason.

Jagannathan and Stephens 2003 [9] did a comparative analysis on firms which repurchase frequently to those who repurchase occasionally. The parameters used were motives, market performance and subsequent operating performance. Their findings were that infrequent repurchases received a strong positive reaction from the market, though there was not much evidence of improved operating performance post buyback, from their study. It was also felt that infrequent repurchases were made by smaller firms with greater variability in operating income, lower institutional ownership and low market to book values. The study by Bradford 2003 [10] examined the post event (buyback) performance through buy and hold abnormal returns and cumulative abnormal returns on a sample of 723 announcements of open market repurchase by US firms. The findings supported the hypothesis on abnormal returns of 22.66 per cent and 13.98 per cent for one year and two-year post buyback.

Bozanic 2010 [11] investigated when and why managers repurchase shares in the open market. The research found evidence that firms which make repurchases are jointly timing their repurchases to perceived undervaluation and the presence of discretionary cash flow. Liano 2003 [12] conducted a comparison across industries in terms of the magnitude of short-term and long-term returns after the repurchase announcement. Their findings were that firms earn positive excess returns during the five-day announcement window which were varies across industries. They thus concluded that industry affiliation does play a significant role when analyzing buybacks.

Among the research works done in the Indian context, Hyderabad 2009 [13] examined the impact of multiple buyback offers in India. Market reaction to multiple offers is in contradiction to signaling hypothesis predictions. The initial or infrequent repurchases earn lower announcement day returns as compared to frequent or subsequent repurchases. A further study by Hyderabad 2009b [14] analyzed the impact of OMR on stock prices and their findings indicated that 
signaling hypothesis was true in the Indian context for open market buybacks, unlike the findings for US firms. Gupta 2006 [15] attempted to find the announcement returns for seven subsequent repurchases. He observes a decline in the AAR for $-1,0$ and +1 days for five companies announcing second repurchase program as compared to first repurchase announcement. Rajagopalan and Shankar 2013 [16] examined the stock market reaction around buyback announcements made during a 10-year period between 2000-01 and 2009-10 based on different market conditions in the two stages. The results showed evidence of semi-strong form of efficiency during the two periods considered, and stated that there were different dosages in the reaction (signaling) of the Indian stock market to buyback announcements in accordance with differing market conditions considered. Thus, the study found that market condition hypothesis is applicable to the Indian context also. On the other hand, Ishwar 2010 [17] in his study showed that very weak signaling of Indian buybacks in the stock market and opined that the information content did not favor undervaluation signaling by observing a statistically insignificant AAR on the announcement day.

Gupta, et al. 2014 [18] tested for the signaling effect of buyback (both through open market and tender offer) on a sample of 58 Indian companies and found no evidence that buybacks trigger market reaction in stock prices when buybacks take place both through tender offer and open market offer. Further research on the signaling effect of buybacks was conducted by Sadaf, et al. 2016 [19] who examined the signaling effect of the payout decisions namely, cash dividends and share repurchases on BSE 500 index companies. They attempted to uncover the underlying forces behind the firm's choices of payout policy in the Indian context. It was observed that cash dividends are not perceived by investors as positive signals as they prefer their earnings to be retained by the companies for growth prospects.

Therefore, the results of the studies on different methods of buybacks were mixed with regard to the comparative information signaling ability both in international and Indian markets. Our research focuses on the signaling impact through open market repurchases.

\section{Research Design and Methodology}

Buybacks can be done either through the tender offer route or through open market purchases. In the former, the company fixes a buyback price and accepts shares on a proportionate basis during the buyback period.

Shareholders will be sent a letter of offer; a form is to be filled in with the necessary details and sent back to the company accompanied by the required documents. Promoters are allowed to tender their shares in this route. Under open market purchases, the company specifies a maximum price and buys back shares from the market during a defined time period. Promoters cannot take part in this route. SEBI (the Securities and Exchange Board of India) has mandated a reservation of 15 per cent of the buyback offer for retail investors with 
holding of up to 2 lakh (market value as on record date).

When companies decide to take the open market route to buyback, investors need to take into account a few things.

One, although the company may declare a maximum buyback price, it does not mean that the investors who sell during the buyback period will realize that maximum price.

The company could actually buy in several tranches and at different prices and the entire process is executed like any other buy/sell transactions in a market.

It is also possible that they may not use the entire amount set aside for the buyback.

A 2013 SEBI regulation makes it mandatory to use at least half the amount originally intended for the buyback, subject to certain exceptions such as the stock price (i.e. volume weighted average price) moving over the maximum buyback price during the buyback period. Our empirical analysis is limited to open market purchases, as the buyback route for companies during FY 2016.

\subsection{Data Source}

Buybacks have been listed from SEBI's website and the criteria for selection of companies were to identify the companies going for open market repurchases in FY2016. Prowess CMIE (Centre for Monitoring Indian Economy), Capitaline database and BSE sites were the sources from which the daily share price data and their respective dates of announcements based on the Board meeting were identified (Table 1). At the outset, 45 companies were identified as going for buyback through open market repurchases. The companies for inclusion in the sample were further filtered for:

- Availability of public/media announcement date;

- Price data for all trading days included in estimation and event periods;

- There was no other confounding event for the company.

Based on these three criteria, the number of companies identified for our sample was 30 firms.

\subsection{Methodology}

The standard event study methodology has been adapted for the analysis. It is a standard practice in the areas related to various market events such as dividend, bonus shares, mergers and acquisition, dividend, stock splits, share repurchase etc. Event study examines market reaction by finding abnormal return. The study uses the Market Model Method. The expected rate of return on the security was calculated using the market model. The model parameters were estimated by regressing daily stock return on the market index over the estimation period.

Event study methodology is used primarily to test the null hypothesis that the market is efficient in terms of information efficiency and within the ambit of market efficiency to examine the impact of buyback announcement on the security 
Table 1. Companies with buyback through OMR and their announcement dates.

\begin{tabular}{|c|c|c|}
\hline S No. & Company & Buyback Announcement Date \\
\hline 1 & Nucleus Software Exports & $6 / 28 / 2017$ \\
\hline 2 & HCL Technologies & $5 / 22 / 2017$ \\
\hline 3 & Gujarat Apollo Industries Ltd. & $4 / 28 / 2017$ \\
\hline 4 & ICRA Limited & $2 / 9 / 2017$ \\
\hline 5 & Ramco Cements Limited & $2 / 7 / 2017$ \\
\hline 6 & NLC India & $2 / 7 / 2017$ \\
\hline 7 & Welspun Enterprise & $2 / 7 / 2017$ \\
\hline 8 & Infinite Computer Solutions & $12 / 20 / 2016$ \\
\hline 9 & Vardhaman & $11 / 29 / 2016$ \\
\hline 10 & Ambika Cotton & $11 / 28 / 2016$ \\
\hline 11 & Indiabulls Real Estate Limited & $11 / 24 / 2016$ \\
\hline 12 & Fineotex Chemical Limited & $11 / 14 / 2016$ \\
\hline 13 & Laxmi Machines & $11 / 8 / 2016$ \\
\hline 14 & Aarti Industries & $10 / 25 / 2016$ \\
\hline 15 & Transpek & $10 / 13 / 2016$ \\
\hline 16 & Disha Industries & $9 / 27 / 2016$ \\
\hline 17 & COAL India Limited & $8 / 31 / 2016$ \\
\hline 18 & Sun Pharma & $7 / 4 / 2016$ \\
\hline 19 & Reddy's Laboratory & $4 / 20 / 2016$ \\
\hline 20 & TIPS Industries & $11 / 18 / 2015$ \\
\hline 21 & Crisil Limited & $6 / 30 / 2015$ \\
\hline 22 & OnMobile Global Ltd. & $12 / 16 / 2014$ \\
\hline 23 & Avantel Ltd. & $8 / 5 / 2014$ \\
\hline 24 & Motilal Oswal & $6 / 11 / 2014$ \\
\hline 25 & Edelweiss Financial Services Ltd. & $5 / 6 / 2014$ \\
\hline 26 & Allcargo Logistics Ltd. & $12 / 29 / 2016$ \\
\hline 27 & Hexaware Technologies Ltd. & $12 / 22 / 2016$ \\
\hline 28 & Techno Electric \& Engineering Ltd. & $2 / 13, / 2017$ \\
\hline 29 & Varrdhman Textiles Ltd. & $11 / 28 / 2016$ \\
\hline 30 & Vyapar Industries Ltd. & $3 / 29 / 2017$ \\
\hline
\end{tabular}

prices and thus wealth creation for the shareholders. The dates of the meeting of the Board of Directors regarding the announcement of buybacks were denoted as the "event day", and the days surrounding the event day (20 days before and 20 days after the event) were denoted as "event window". Up to a 365-day period prior to the first day of the event window ( -365 to -21 days) was considered as the "estimation window". 
The author has used even methodology through excel and the other statistical analysis is done using SPSS (Table 2).

The BSE 500 index returns were taken as "proxy" for the market returns of 360 days during the estimation window and the respective shares were regressed against the proxy to determine the constant and the regression coefficient to calculate the expected returns during the event window (Market Model). The difference between the actual return and the expected return during the event window is considered as the "Abnormal Returns" (AR). The Average Abnormal Returns (AARs) were calculated for each day during the event window across securities for analyzing the ARs around the event. The percentage returns for the securities have been taken as the core data for analysis.

$\mathrm{AR}=$ Actual return of security at day - Expected return of security at day

$$
\mathrm{AAR}=\frac{1}{n} \sum \text { Abnormal Returns around the event }
$$

The Cumulative Average Abnormal Returns (CAARs) were also calculated for analyzing the price adjustment process. CAAR is the sum of daily AARs during the event window.

$$
\text { Cumulative Average Abnormal Return }(\mathrm{CAAR})=\sum_{-k}^{+k} \mathrm{AAR}_{t}
$$

While the AARs are used to analyze the information content of buybacks and CAARs are used to analyze the adjustments of prices to new information, to check the efficiency of market, student's $t$-test has been applied. To find out whether the abnormal returns and the cumulative abnormal returns differed significantly from zero during the two market conditions, the following null hypotheses were framed:

\section{$\mathrm{H}_{0}$ : Average Abnormal Returns $=0$. \\ $\mathrm{H}_{1}$ : Average Abnormal Returns $\neq 0$.}

The test statistics is: $t=\sqrt{N} \frac{\text { AAR }}{\text { S.E. }}$

The methodology adopted can be summarized in the steps below:

\section{Research Findings}

\subsection{Analysis of Market Reaction}

\section{Impact on Stock Return:}

Table 3 lists down the stock return for all the 30 companies for the specific days before and after the announcement of the buyback decision.

It can be seen from the table above that out of 30 companies, on the day of the announcement, 16 companies showed positive returns, with maximum return being 4.45 percent by Tips Industries. On the $1^{\text {st }}$ day post announcement the stock returns were positive for 18 companies and on the $20^{\text {th }}$ day post announcement, 15 companies were exhibiting positive returns. When we compare the returns, pre-announcement it is observed that 19 companies showed positive returns while 20 days prior, 16 companies had positive returns to their stocks. 
Table 2. Methodology for event study.

1 Enlisted 30 stocks with their Buyback announcement date

2 Collection of historical data for every company (Source: Capitaline.com, Google finance)

3 Regression of stock prices (from $-365^{\text {th }}$ day to $1^{\text {st }}$ day) with respect to reference index (BSE SENSEX)

4 Formulation of Correlation equation for every individual stock

5 Using the correlation equation finding the expected return from $-20^{\text {th }}$ day to $+20^{\text {th }}$ day

6 Finding an Average Abnormal Return (AAR) for every stock using data of actual return and expected return

7 Finding the value of Cumulative Average Abnormal Return (CAAR) for descending dates from $-20^{\text {th }}$ day to $+20^{\text {th }}$ day

8 Finding the $t$-stat value for descending dates from $-20^{\text {th }}$ day to $+20^{\text {th }}$ day

For deduction of conclusion the deviation of actual return from expected return has been observed till the $20^{\text {th }}$ day after buyback announcement \& result has been tabulated on the basis of AAR

Abnormal Return (AR) = Actual Return - Expected Return

Average Abnormal Return (AAR) $=(1 / n) S(1$ to $n) \mathrm{AR}_{n}$

9 Cumulative Average Abnormal Return $(\mathrm{CAAR})=S(t-k$ to $+k) \mathrm{AAR}_{t}$

$t$-stat $=n^{0.5} * A A R_{t} / S_{t}$

where,

$n=$ sample size, $S=$ Population standard deviation, $-k=-20^{\text {th }}$ day, $+k=20^{\text {th }}$ day

Table 3. Stock return for specific days before and after buyback.

\begin{tabular}{|c|c|c|c|c|c|c|c|c|}
\hline S. No & Company & $-20^{\text {th }}$ day & $-10^{\text {th }}$ day & $-1^{\text {st }}$ day & $0^{\text {th }}$ day & $+1^{\text {st }}$ day & $+10^{\text {th }}$ day & $+20^{\text {th }}$ day \\
\hline 1 & Nucleus Software Exports & $-0.72 \%$ & $-0.31 \%$ & $0.61 \%$ & $0.51 \%$ & $-3.97 \%$ & $-0.32 \%$ & $-0.46 \%$ \\
\hline 2 & HCL Technologies & $-0.32 \%$ & $1.29 \%$ & $-0.37 \%$ & $1.24 \%$ & $1.06 \%$ & $0.00 \%$ & $-0.85 \%$ \\
\hline 3 & Gujarat Apollo Industries Ltd. & $-1.13 \%$ & $-1.95 \%$ & $0.01 \%$ & $0.25 \%$ & $0.35 \%$ & $-0.59 \%$ & $-1.40 \%$ \\
\hline 4 & ICRA Limited & $1.32 \%$ & $1.87 \%$ & $-0.58 \%$ & $0.00 \%$ & $-1.97 \%$ & $-0.11 \%$ & $-0.32 \%$ \\
\hline 5 & Ramco Cements Limited & $-0.55 \%$ & $-0.15 \%$ & $0.61 \%$ & $-4.59 \%$ & $-0.80 \%$ & $-0.30 \%$ & $-0.35 \%$ \\
\hline 6 & NLC India & $1.71 \%$ & $-0.68 \%$ & $-0.36 \%$ & $0.24 \%$ & $0.40 \%$ & $1.09 \%$ & $-0.42 \%$ \\
\hline 7 & Welspun Enterprise & $-0.66 \%$ & $2.00 \%$ & $0.63 \%$ & $0.46 \%$ & $0.83 \%$ & $3.13 \%$ & $0.79 \%$ \\
\hline 8 & Infinite Computer Solutions & $-1.60 \%$ & $0.15 \%$ & $0.54 \%$ & $-0.45 \%$ & $0.41 \%$ & $-1.19 \%$ & $-1.07 \%$ \\
\hline 9 & Vardhaman & $-0.43 \%$ & $-0.50 \%$ & $0.80 \%$ & $0.08 \%$ & $-0.70 \%$ & $0.58 \%$ & $-1.68 \%$ \\
\hline 10 & Ambika Cotton & $2.25 \%$ & $-0.45 \%$ & $-1.25 \%$ & $-0.83 \%$ & $0.15 \%$ & $-0.39 \%$ & $2.27 \%$ \\
\hline 11 & Indiabulls Real Estate Limited & $1.68 \%$ & $-16.11 \%$ & $9.28 \%$ & $-2.09 \%$ & $2.10 \%$ & $1.83 \%$ & $1.66 \%$ \\
\hline 12 & Fineotex Chemical Limited & $2.85 \%$ & $3.14 \%$ & $2.56 \%$ & $-3.08 \%$ & $-5.52 \%$ & $-2.38 \%$ & $-1.17 \%$ \\
\hline 13 & Laxmi Machines & $-3.73 \%$ & $5.20 \%$ & $-2.06 \%$ & $-2.58 \%$ & $-1.11 \%$ & $3.10 \%$ & $-0.14 \%$ \\
\hline 14 & Aarti Industries & $7.26 \%$ & $-5.00 \%$ & $1.11 \%$ & $1.01 \%$ & $-0.37 \%$ & $-0.30 \%$ & $3.38 \%$ \\
\hline 15 & Transpek & $0.37 \%$ & $-1.25 \%$ & $1.24 \%$ & $0.40 \%$ & $-1.40 \%$ & $-2.13 \%$ & $0.26 \%$ \\
\hline 16 & Disha Industries & $0.60 \%$ & $-2.25 \%$ & $0.28 \%$ & $0.68 \%$ & $-0.80 \%$ & $0.05 \%$ & $-0.24 \%$ \\
\hline 17 & COAL India Limited & $-0.81 \%$ & $3.10 \%$ & $-0.91 \%$ & $-0.65 \%$ & $1.43 \%$ & $-0.04 \%$ & $0.92 \%$ \\
\hline 18 & Sun Pharma & $-1.46 \%$ & $-1.08 \%$ & $-0.37 \%$ & $0.65 \%$ & $0.63 \%$ & $0.61 \%$ & $0.79 \%$ \\
\hline 19 & Reddy's Laboratory & $0.13 \%$ & $-1.61 \%$ & $-0.85 \%$ & $0.53 \%$ & $0.58 \%$ & $-0.83 \%$ & $0.00 \%$ \\
\hline 20 & TIPS Industries & $-1.74 \%$ & $12.85 \%$ & $5.33 \%$ & $4.45 \%$ & $-3.16 \%$ & $-1.67 \%$ & $1.51 \%$ \\
\hline 21 & Crisil Limited & $1.02 \%$ & $-0.50 \%$ & $-1.93 \%$ & $-1.74 \%$ & $2.26 \%$ & $1.10 \%$ & $0.89 \%$ \\
\hline
\end{tabular}




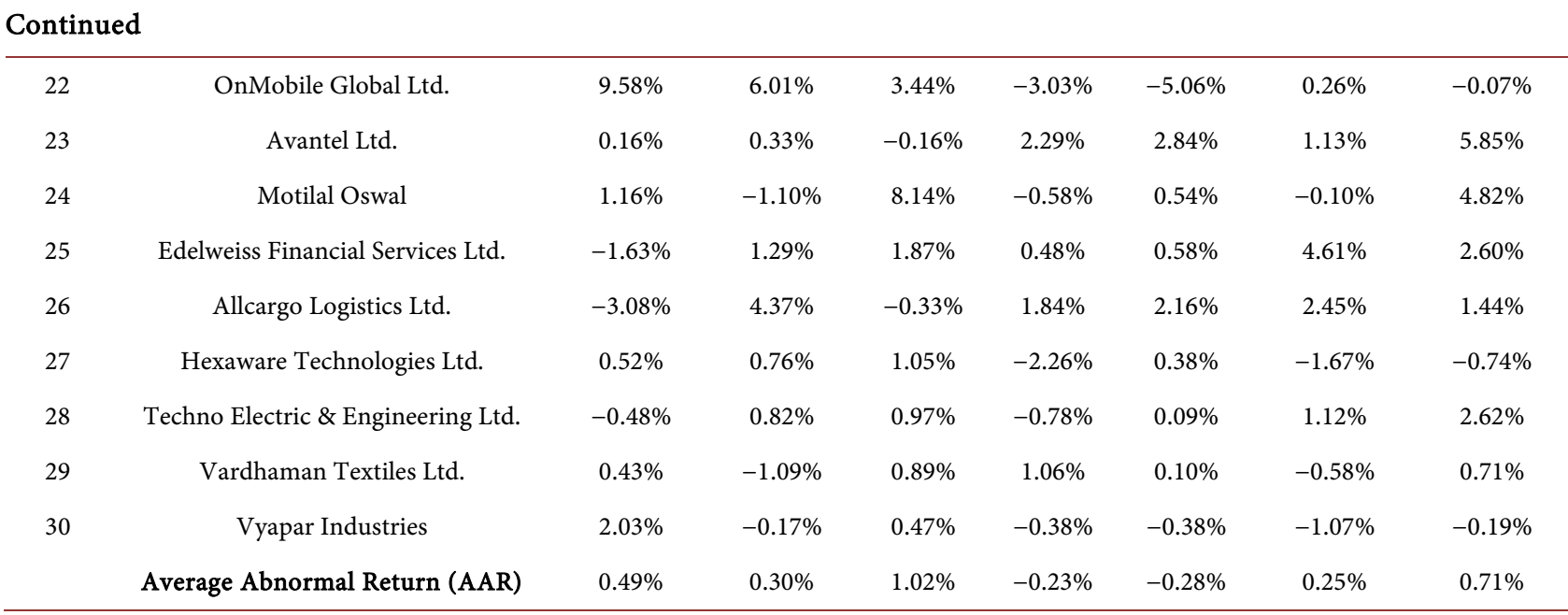

Table 4. Deviation in abnormal returns.

\begin{tabular}{ccccc}
\hline Return & $\mathbf{0}^{\text {th }}$ day & $+\mathbf{1}^{\text {st }}$ day & $+10^{\text {th }}$ day & $\mathbf{+ 2}^{\text {th }}$ day \\
\hline$-5 \%$ & 0 & 2 & 0 & 0 \\
$-2 \%$ to $-5 \%$ & 6 & 2 & 2 & 0 \\
$-2 \%$ to $\%$ & 8 & 8 & 14 & 15 \\
$0 \%$ to $2 \%$ & 14 & 14 & 10 & 9 \\
$2.01 \%$ to $\%$ & 2 & 4 & 4 & 5 \\
$5.01 \%$ to $20 \%$ & 0 & 0 & 0 & 1 \\
$>20.00 \%$ & 0 & 0 & 0 & 0 \\
\hline Deviation in Abnormal Return & $0^{\text {th }}$ day & $+1^{\text {st }}$ day & $+10^{\text {th }}$ day & $+20^{\text {th }}$ day \\
\hline up to $2 \%$ & 22 & 22 & 24 & 24 \\
$2 \%$ to $5 \%$ & 8 & 6 & 6 & 5 \\
more than $5 \%$ & 0 & 2 & 0 & 1 \\
Total No. of Firms & & & 30 & \\
\hline
\end{tabular}

Thus, we do not find any pattern on the stock returns post buyback announcement.

It is also seen that the average abnormal returns was negative on the day of announcement and continued to be negative for the $1^{\text {st }}$ day, only for the $10^{\text {th }}$ day and the $20^{\text {th }}$ day, the AAR was positive. However, the AAR had been positive for the $1^{\text {st }}$ day, $10^{\text {th }}$ day and $20^{\text {th }}$ day prior to the announcement of buyback, thus negating the signaling hypothesis (Table 4 \& Table 5).

The impact of buyback on stock return was mixed, with most of the positive returns in the range of $0 \%$ to $2 \%$. No visible pattern was observed in the stock return for most of the companies. The number of companies with positive impact was found to be declining after the initial few days of announcement.

\subsection{Average Abnormal Return (AAR) and Cumulative Abnormal Return (CAAR) (Figure 1, Table 6)}

The Average Abnormal Return (AAR) was negative on the day of announcement 
Table 5. Positive returns of buyback.

\begin{tabular}{ccccc}
\hline \multicolumn{5}{c}{ Positive impact of buyback } \\
\hline Return & $0^{\text {th }}$ day & $+1^{\text {st }}$ day & $+10^{\text {th }}$ day & $+20^{\text {th }}$ day \\
\hline $0 \%$ to $2 \%$ & 14 & 14 & 10 & 9 \\
\hline $2.01 \%$ to $5 \%$ & 2 & 4 & 4 & 1 \\
\hline $5.01 \%$ to $20 \%$ & 0 & 0 & 0 & 0 \\
\hline$>20.00 \%$ & 0 & 0 & 0 & 15 \\
\hline & 16 & 18 & & \\
\hline
\end{tabular}

Figure 1. Percentage of AAR and CAAR.

Table 6. T-statistics for AAR and CAAR.

\begin{tabular}{|c|c|c|c|c|}
\hline Day & AAR & Std. Deviation (St) & t-statistic & CAAR \\
\hline+20 & $0.71 \%$ & 0.0175 & 2.231 & $3.44 \%$ \\
\hline+19 & $0.11 \%$ & 0.0165 & 2.131 & $3.24 \%$ \\
\hline+18 & $-0.11 \%$ & 0.0168 & -0.342 & $2.73 \%$ \\
\hline+17 & $-0.42 \%$ & 0.0260 & -0.887 & $2.83 \%$ \\
\hline+16 & $0.14 \%$ & 0.0210 & 0.370 & $3.26 \%$ \\
\hline+15 & $-0.35 \%$ & 0.0116 & -1.679 & $3.11 \%$ \\
\hline+14 & $0.06 \%$ & 0.0154 & 0.227 & $3.47 \%$ \\
\hline+13 & $-0.84 \%$ & 0.0197 & -2.338 & $3.40 \%$ \\
\hline+12 & $-0.06 \%$ & 0.0229 & -0.135 & $4.25 \%$ \\
\hline+11 & $-0.12 \%$ & 0.0173 & -0.372 & $4.30 \%$ \\
\hline+10 & $0.25 \%$ & 0.0157 & 0.858 & $4.42 \%$ \\
\hline+9 & $0.93 \%$ & 0.0401 & 1.274 & $4.17 \%$ \\
\hline+8 & $-0.24 \%$ & 0.0230 & -0.582 & $3.24 \%$ \\
\hline+7 & $0.13 \%$ & 0.0249 & 0.285 & $3.48 \%$ \\
\hline+6 & $0.38 \%$ & 0.0183 & 1.141 & $3.35 \%$ \\
\hline
\end{tabular}




\section{Continued}

\begin{tabular}{|c|c|c|c|c|}
\hline+5 & $-0.81 \%$ & 0.0141 & -3.134 & $2.97 \%$ \\
\hline+4 & $-0.72 \%$ & 0.0240 & -1.648 & $3.78 \%$ \\
\hline+3 & $-0.17 \%$ & 0.0149 & -0.625 & $4.50 \%$ \\
\hline+2 & $-0.76 \%$ & 0.0195 & -2.148 & $4.67 \%$ \\
\hline+1 & $-0.28 \%$ & 0.0197 & -0.774 & $5.44 \%$ \\
\hline $0^{\text {th }}$ day & $-0.23 \%$ & 0.0177 & -0.708 & $5.72 \%$ \\
\hline-1 & $1.02 \%$ & 0.0252 & 2.216 & $5.95 \%$ \\
\hline-2 & $0.83 \%$ & 0.0293 & 1.560 & $4.92 \%$ \\
\hline-3 & $-0.53 \%$ & 0.0180 & -1.611 & $4.09 \%$ \\
\hline-4 & $0.05 \%$ & 0.0174 & 0.148 & $4.62 \%$ \\
\hline-5 & $0.43 \%$ & 0.0191 & 1.243 & $4.57 \%$ \\
\hline-6 & $0.33 \%$ & 0.0181 & 0.990 & $4.14 \%$ \\
\hline-7 & $-0.19 \%$ & 0.0225 & -0.467 & $3.81 \%$ \\
\hline-8 & $0.12 \%$ & 0.0307 & 0.214 & $4.00 \%$ \\
\hline-9 & $1.20 \%$ & 0.0331 & 1.976 & $3.88 \%$ \\
\hline-10 & $0.30 \%$ & 0.0439 & 0.374 & $2.69 \%$ \\
\hline-11 & $-0.09 \%$ & 0.0171 & -0.274 & $2.39 \%$ \\
\hline-12 & $0.19 \%$ & 0.0223 & 0.477 & $2.47 \%$ \\
\hline-13 & $0.01 \%$ & 0.0152 & 0.020 & $2.28 \%$ \\
\hline-14 & $0.73 \%$ & 0.0265 & 1.509 & $2.28 \%$ \\
\hline-15 & $-0.03 \%$ & 0.0154 & -0.116 & $1.54 \%$ \\
\hline-16 & $-0.09 \%$ & 0.0295 & -0.163 & $1.58 \%$ \\
\hline-17 & $0.61 \%$ & 0.0457 & 0.732 & $1.66 \%$ \\
\hline-18 & $-0.21 \%$ & 0.0210 & -0.550 & $1.05 \%$ \\
\hline-19 & $0.77 \%$ & 0.0255 & 1.663 & $1.26 \%$ \\
\hline-20 & $0.49 \%$ & 0.0260 & 1.034 & $0.49 \%$ \\
\hline
\end{tabular}

( $0^{\text {th }}$ day), and the subsequent day ( $1^{\text {st }}$ day). The AAR is negative for majority of days after the announcement indicating that buyback euphoria is only a temporary phenomenon and fails to provide benefits over longer-time horizon. The CAR on the announcement day is $5.72 \%$ while for the entire 40 -day period it is $3.44 \%$. Since the CAAR values have been decreasing as the days come close to event day, it means that the buyback has a substantial impact to bring down the CAARs which was maintained before announcement or prevent days.The overall CAR falls by $2.28 \%$ in the post-offer period. The fall in CAAR in post-offer period is attributed to negative movement in prices. The negative overall CAR in post-offer period is anathema to the signaling hypothesis, which predicts that the repurchase announcements are made to reverse the negative trend in market prices in pre-offer period. Vermaelen (1981) concludes that significant abnormal 
returns before the announcement can always be explained on the basis of information leakages or prior insider trading.

These findings are in direct contrast with many past studies, where the announcement effect is pronounced and leads to significantly high (low) returns. However, this may be an encouraging sign for the Indian stock market. Buyback of shares is essentially a method of realigning the capital structure of the company and as such does not contradict the caveat of shareholder wealth maximization. The fact that the announcement of buyback is not having a significant effect on the share price implies that the information is quickly subsumed in the share price and thus the market is moving towards being informational efficient.

\section{Conclusions and Recommendations}

This study has analyzed the impact of buyback through open market repurchases for FY 2016 on a dataset of 30 companies. The author has used event study methodology for conducting the analysis. The 30 companies that we have taken are mostly small cap and most of them do not come in Nifty 100 and the volatility among few of them is much higher than those which fall in the Nifty 50 and Nifty 100. It is also seen that the companies' poor corporate governance could not lead to positive reaction from the market after the buyback announcement. Also if the company performance in terms of fundamentals is weak at the time of announcement, market may not react favorably by the buyback news. This was observed specifically in the case of Dr. Reddy's Laboratories whose weak results prove a bad prescription.

For Dr. Reddy's and OnMobile Global, the stocks were victimized on the valuation side on the back of exit of some investors that resulted in a fall in the stock price. We thus rationalize that buyback route was chosen to preempt the stock prices from going down further. The fact that the announcement of buyback is not having a significant effect on the share price implies that the information is quickly subsumed in the share price and thus the market is moving towards being informational efficient. Significant abnormal returns before the announcement can always be explained on the basis of information leakages or prior insider trading. Buybacks can also be lucrative to shareholders if the company's stock is undervalued when it's bought back. Moreover, the companies that come in a range of $-5 \%$ to $5 \%$ are very small by their market capitalization so few traders exploited this arbitrage opportunity.

Some of the recommendations are:

- The companies whose earning visibility is not great get more visibility by buyback thereby raising return on equity to investors.

- When buybacks change the capital structure of a company, they may have a detrimental impact on the credit ratings. Since it drains cash reserves that can serve as a cushion when times get tough.

- In some cases, a leveraged buyback can be used as a means to fend off a hostile bidder. The company takes on additional debt to repurchase stocks 
through a buyback program. Such leveraged buybacks can be successful in thwarting hostile bids by both raising the share value and adding a great deal of unwanted debt to the company's balance sheet.

- To make buyback successful, there is a certain percentage of stock that SEBI needs to reserve for small shareholders.

- The company needs to make sure that good corporate governance needs to be there when announcing buyback, otherwise, many small shareholders fail to tender their shares through open market resulting in arbitrage opportunity for others. This leads to negative investor sentiment which can lead to the decline in stock prices after buyback.

Our research refutes the signaling hypothesis and we conclude that buybacks, may be resorted to by companies for cash flow hypothesis or as a preventive measure against hostile bids. Since a large set of companies in our dataset are small cap companies, there is a high probability that the buyback is undertake to instill investor confidence. The results of the study imply that the information related to the announcement of the buyback is already reflected in the share price and this reflects that markets are slowly moving towards information symmetry, and inefficiencies are being dealt with. The findings also indicate that OMRs are not the route of buyback adopted by companies for signaling hypothesis as FTP, offer shares at a substantial premium and thus are largely undertaken to signal of the undervaluation of the stock.

\section{Limitations of the Study and Scope for Future Research}

The study has taken a small sample of 30 companies going for OMR route and the analysis is restricted to buybacks during one year only. The results could be different if more companies are taken and a wider time horizon be considered. The study has also not compared the abnormal returns of stocks with those under tender offer route. For identifying the event window, a 30 days period is chosen. The same can be extended to see the impact on stock prices. The companies were not segregated broadly on the basis of sectors or market capitalization to see if any trend could be observed.

The impact of buyback on the EPS and other financial ratios can also be assessed for the quarter after the buyback, and compared with the preceding quarter to see if the objective of buyback is to improve financial indicators. Further research can be done to analyze if OMPs are specifically undertaken to offset any dilution which companies may have had on account of stock options, among others and because of free cash. An analysis of the life cycle stage of these companies will also help in understanding if the companies are in their maturity stage and thus, further investment in capital expenditure will not yield sufficient ROI, and thus the free cash flow hypothesis is the reason for buyback.

\section{Acknowledgements}

The infrastructure support provided by Fore School of Management, New Delhi 
in supporting this research is greatly appreciated.

\section{References}

[1] Nobuyuki, I. (2000) Open-Market Stock Repurchase and Stock Price Behavior When Management Values Real Investment. The Financial Review, 35, 95-108. https://doi.org/10.1111/j.1540-6288.2000.tb01431.x

[2] Jensen, M.C. (1986) Agency Costs of Free Cash Flow, Corporate Finance and Takeovers. American Economic Review, 76, 323-329.

[3] Stephens, C.P. and Weisbach, M.S. (1998) Actual Share Reacquisitions in Open Market Repurchase Programs. Journal of Finance, 53, 313-333.

https://doi.org/10.1111/0022-1082.115194

[4] Vermaelen, T. (1981) Common Stock Repurchases and Market Signaling: An Empirical Study. Journal of Financial Economics, 9, 139-183.

https://doi.org/10.1016/0304-405X(81)90011-8

[5] Ikenberry, D., Lakonishok, J. and Vermaelen, T. (1995) Market under Reaction to Open Market Repurchases. Journal of Financial Economics, 39, 181-208. https://doi.org/10.1016/0304-405X(95)00826-Z

[6] Comment, R. and Jarrell, G.A. (1991) The Relative Signaling Power of Dutch Auction and Fixed Price Tender Offers and Open Market Share Repurchase. Journal of Finance, 46, 1243-1271. https://doi.org/10.1111/j.1540-6261.1991.tb04617.x

[7] Kim, J. (2008) Buyback Trading of Open Market Share Repurchase Firms and the Return Volatility Decline. International Journal of Managerial Finance, 3, 316-337. https://doi.org/10.1108/17439130710824343

[8] Stanley, B. (2006) An Empirical Study of Stock Repurchase Programs among Fortune 100 Companies. Corporate Finance Review, 11, 22.

[9] Jagannathan, M. and Stephens, C. (2003) Motives for Multiple Open Market Repurchase Programs. Financial Management, 32, 71-91.

[10] Bradford, B.M. (2008) Open-Market Common Stock Repurchases and Subsequent Market Performance. The Journal of Business and Economic Studies, 14, 45.

[11] Bozanic, Z. (2010) Managerial Motivation and Timing of Open Market Share Repurchases. Review of Quantitative Finance and Accounting, 34, 517-531. https://doi.org/10.1007/s11156-009-0145-8

[12] Liano, K. (2003) Market Reaction to Open Market Stock Repurchases and Industry Affiliation. Quarterly Journal of Business and Economics, 42, 97.

[13] Hyderabad, R. (2009) Market Reaction to Multiple Buybacks in India. Indore Management Journal, 1, 18-47.

[14] Hyderabad, R. (2009) Price Performance Following Share Buyback Announcements in India Vision. The Journal of Business Perspectives, 13.

[15] Gupta, A. (2006) Share Price Behavior around Buybacks in India. The ICFAI Journal of Applied Finance, 12, 26-40.

[16] Rajagopalan, N.V.R. and Shankar, H. (2013) Buyback Announcements and Stock Market Reaction in India: 83 Testing the Market Condition Hypothesis. The IUP Journal of Applied Finance, 19, 64-83.

[17] Ishwar, P. (2010) Stock Price Responses to the Announcement of Buyback of Shares in India. Indian Journal of Commerce and Management Studies, 1, 14-29.

[18] Gupta, S., Kalra, N. and Bagga, R. (2014) Do Buybacks Still Hold Their Signaling 
Strength? An Empirical Evidence from Indian Capital Market. Amity Business Review, 15, 2-18.

[19] Sadaf, A., Singh, A. and Jain, P.K. (2016) Signaling Mechanism of Corporate Payout Policy: A Case of Indian Firms. Accounting, 2, 53-66. 